\title{
KERUKUNAN UMAT BERAGAMA DI INDONESIA MENURUT TARMIZI TAHER
}

\author{
Junita Br. Surbajti ${ }^{1}$, Asim $^{2}$ \\ ${ }^{1,2}$ UIN Sulthan Thaha Saifuddin Jambi \\ surbaktijunita13@uinjambi.ac.id
}

\begin{abstract}
Abstrak
Isu keberagaman masyarakat di Indonesia menjadi tema menarik sepanjang sejarah, terlebih ketika berbicara mengenai kerukunan umat beragama dalam masyarakat multi kultur. Keberagaman agama akan menjadi kekuatan bangsa manakala agama-agama mampu hidup berdampingan secara menyenangkan dalam sebuah negara. Namun, keberagaman dapat memicu konflik ketika masyarakat memaksakan kebenaran agamanya di tengah keberagaman agama. Salah satu tokoh yang paling konsen dalam menciptakan kerukunan umat beragama di Indonesia adalah Tarmizi Taher. Melihat situasi keberagaman masyarakat di Indonesia, Tarmizi Taher berpendapat bahwa kerukunan antar umat beragama dapat diwujudkan jika masingmasing agama mengakui prinsip umum sebagai landasan bersama dalam merespon situasi keanekaragaman.
\end{abstract}

Kata Kunci : Kerukunan, Tarmizi Taher, Masyarakat Beragama

\section{PENDAHULUAN}

Agama merupakan tema menarik dalam diskusi sepanjang sejarah. Isu keagamaan semakin menarik ketika dihadapkan dengan masyarakat yang majemuk dan multikultur. Agama seyogyanya diharapkan sebagai paradigma alternatif dalam membingkai sejarah peradaban manusia yang akan datang. Pada kenyataannya, pandangan ekslusif cukup banyak mendorong disintegrasi masyarakat. Kasus Poso misalnya, konflik yang berbau SARA ini mengakibatkan kerusuhan massal hingga jatuhnya banyak korban jiwa, rusaknya tempat ibadah, rumah warga serta kerugian materi yang tidak sedikit. Konflik yang berlangsung pada tahun 1998 hingga 2001 ini memaksa masyarakat Poso tanpa terkecuali terlibat dalam konflik berdarah yang berkepanjangan (Gogali: 2009,21). Pandangan masyarakat mengenai kasus ini tentu berbeda-beda, tergantung darimana mereka melihat akar permasalahannya. Jika isu keagamaan dimasukkan 
dalam konflik sosial, maka besar kemungkinan masyarakat melihatnya sebagai konflik antar agama. Meskipun sebenarnya, tidak semua konflik sosial yang terjadi di Poso bernuansa konflik keagamaan. Pemikiran seperti inilah yang menjadi salah satu faktor mengentalnya konflik atau bahkan kekerasan antar umat beragama. Oleh sebab itu, persoalan semacam ini pada akhirnya akan merugikan pada tingkat personal, masyarakat, bangsa dan negara. Melihat fenomena seperti inilah pentingnya dilakukan berbagai pendekatan untuk menciptakan kehidupan keberagamaan yang kondusif, yang saling harga menghargai satu sama lain, mampu berdialog, dan tetap menjaga kerukunan antar umat beragama.

Tarmizi Taher berpendapat bahwa agama dapat menjadi salah satu kekuatan bagi manusia dalam menciptakan keadilan dan perdamaian. Sebakiknya, semangat keagamaan yang tidak toleran, tidak saling menghargai, dapat menyebabkan konflik, ketegangan, bahkan kehancuran masyarakat suatu bangsa(Azra: 1998, 421).Tarmizi Taher juga berpendapat bahwa, merupakan tanggung jawab setiap umat beragama untuk mempertahankan kerukunan umat beragama, yang pada gilirannya merupakan salah satu hal penting bagi persatuan dan kesatuan, serta kelanjutan pembangunan nasional sebagai pengalaman pancasila.Nilai dan norma agama diharapkan menjadi landasan spiritual, moral dan etik pembangunan. Tidak ada langkah yang lebih baik dari pada mengembangkan saling pengertian, saling hormat dan kerja sama diantara para pemeluk berbagai agama (Azra: 1998, 421). Oleh sebab itu, tulisan ini akan menjelaskan lebih lanjut mengenai pemikiran Tarmizi Taher mengenai Kerukunan Umat Beragama dalam setting wilayah di Indonesia.

\section{METODE PENELITIAN}

Metode penelitian yang digunakan oleh penulis adalah penelitian pustaka (Library research). Oleh sebab itu, seluruh data yang dituangkan dalam penelitian ini berasal dari bahan-bahan tertulis, yang secara garis besar terdiri dari dua data yaitu data primer dan data sekunder. Data yang dikumpulkan harus berhubungan dengan tema kerukunan umat beragama, sehingga dapat dijadikan sebagai rujukan 
baik sebagai data primer maupun data sekunder. Setelah data terkumpul sesuai dengan permasalahan yang dibahas, maka penulis akan menganalisis data dengan menggunakan kerangka pikir induktif, deduktif, komparatif dan historis.

\section{KONSEP KERUKUNAN UMAT BERAGAMA}

Kerukunan dalam Islam diberi istilah "tasamuh" atau toleransi. "Rukun" juga dari bahasa Arab "ruknun" artinya asas-asas, seperti rukun Islam. Rukun dalam arti adjective adalah baik atau damai. Hal ini sama seperti yang terdapat dalam Kamus Besar Bahasa Indonesia yang berarti perihal hidup damai; rasa rukun; kesepakatan (Departemen Pendidikan Nasional, 1998: 851). Sehingga yang dimaksud dengan toleransi adalah kerukunan sosial, Bukan dalam bidang aqidah Islamiyah (keimanan), karena aqidah telah digariskan secara jelas dalam Alquran dan alhadist. Dalam bidang aqidah atau keimanan seorang muslim hendaknya meyakini bahwa Islam adalah satu-satunya agama dan keyakinan yang dianut sesuai dengan firman Allah dalam surat Al Kafirun, yang artinya; "Katakanlah: Hai orang-orang yang kafir, Aku tidak akan menyembah apa yang kamu sembah, dan kamu bukan penyembah Tuhan yang aku sembah. Dan aku tidak pernah menjadi penyembah apa yang kamu sembah, dan kamu tidak pernah (pula) menjadi penyembah Tuhan yang aku sembah. Untukmulah agamamu dan untukkulah agamaku.” (QS. al-Kafirun: 1$6)$.

Sikap sinkretisme dalam agama yang menganggap bahwa semua agama adalah benar tidak sesuai dan tidak relevan dengan keimanan seorang Muslim serta tidak relevan dengan pemikiran yang logis, meskipun pergaulan sosial dan kemasyarakatan sangat menekankan prinsip toleransi atau kerukunan umat beragama. Apabila terjadi perbedaan pendapat antara anggota masyarakat Muslim tidak perlu menimbulkan perpecahan umat, tetapi hendaklah kembali kepada al Qur'an dan al-hadis.

Dalam sejarah Islam, kerukunan sosial kemasyarakatan telah ditampakkan pada masyarakat Madinah. Pada saat itu Rasul SAW dan kaum 
muslim hidup berdampingan dengan masyarakat Madinah yang berbeda agama, Yahudi dan Nasrani. Konflik yang terjadi kemudian disebabkan oleh pengkhianatan dari orang bukan Islam (Yahudi) yang melakukan persekongkolan untuk menghancurkan umat Islam. Dengan demikian, yang dimaksud dengan kerukunan umat beragama adalah hidup dalam suasana damai walaupun berbeda agama. Kerukunan umat beragama ini menjadi program pemerintah yang meliputi semua agama, semua warga negara Republik Indonesia. Berkenaan dengan sikap keterbukaan kaum muslimin, seorang ahli sejarah Yahudi Max I Dimon, dalam buku Nurcholish Madjid (2000: 192) dikatakan bahwa; Bahasa Arab menjadi bahasa Ibu mereka; khamar, perempuan dan lagu-lagu duniawi menjadi hiburan mereka di waktu luang; filsafat, matematika, astronomi, diplomasi, kedokteran dan sastra merupakan kesibukan mereka sepenuh waktu. Kaum Yahudi belum pernah mengalami hal seperti itu.

\section{LANDASAN HUKUM KERUKUNAN BERAGAMA}

Adapun yang menjadi landasan hukum bagi kerukunan umat beragama di Indonesia adalah: Landasan idiil, yaitu Pancasila (sila pertama, yakni Ketuhanan Yang Maha Esa). Landasan Konstitusional, yakni Undang-Undang Dasar 1945, pasal 29 ayat 1: "Negara berdasar atas Ketuhanan Yang Maha Esa." serta pasal 29 ayat 2 disebutkan: "Negara menjamin kemerdekaan tiaptiap penduduk untuk memeluk agamanya masing-masing dan untuk beribadah menurut agamanya dan kepercayaannya itu". Landasan Strategis, Ketetapan MPR No. IV tahun 1999 tentang Garis-Garis Besar Haluan Negara (GBHN) dan Program PembangunanNasional (PROPENAS) tahun 2000, dinyatakan bahwa sasaran pembangunan bidang agama adalah terciptanya suasana kehidupan beragama dan kepercayaan terhadap Tuhan Yang Maha Esa, yang penuh keimanan dan ketakwaan, penuh kerukunan yang dinamis antar umat beragama dan kepercayaan terhadap Tuhan Yang Maha Esa, secara bersamasama makin memperkuat landasan spiritual moral dan etika bagi pembangunan nasional yang tercermin dalam suasana kehidupan yang harmonis, serta dalam 
kokohnya persatuan dan kesatuan bangsa selaras dengan penghayatan dan pengalaman Pancasila. Terakhir adalah landasan Operasional; (a) UU No. 1/PNPS/1965 Tentang larangan dan pencegahan serta penghinaan agama; (b) Keputusan Bersama Menteri Dalam Negeri dan Menteri Agama RI No. 01/Ber/Mdn/1969 tentang pelaksanaan aparat pemerintah yang menjamin keterlibatan dan kelancaran pelaksanaan dan pengembangan ibadah pemeluk agama oleh pemeluknya; (c) SK Menteri Agama dan Menteri Dalam Negeri RI No. 01/1978 tentang tata cara pelaksanaan penyiaran agama dan bantuan luar kepada lembaga-lembaga keagamaan swasta di Indonesia; dan (d) Surat Edaran Menteri Agama RI No. MA/432/1981 tentang penyelenggaraan hari besar keagamaan.

Islam memandang bahwa doktrin tentang monotheisme tauhid tidak sekedar hanya menjadi pesan milik Islam saja, melainkan juga sebagai hati dan inti dari setiap agama. Pewahyuan bagi Islam berarti penegasan ulang mengenai doktrin tauhid yang sudah dijelaskan sebelumnya oleh agama-agama yang hadir mendahului kerasulan Muhammad SAW. Karena istilah pewahyuan itu pada masyarakat berbeda-beda maka bahasa yang digunakan untuk mengekspresikannya juga berbeda-beda meskipun isi dan substansinya tetap sama. Oleh sebab itu, seharusnya tidak ada lagi konflik akibat perdebatan mengenai ketauhidan antar agama. Islam melarang umatnya berbantahbantahan dengan para penganut kitab suci lain, melainkan dengan cara bijak, termasuk menjaga kesopanan dan tenggang rasa, kecuali terhadap mereka yang bertindak zalim. Dijelaskan dalam al Qur'an, yang artinya: “Dan janganlah kamu berdebat dengan ahli kitab, melainkan dengan cara yang paling baik, kecuali dengan orang-orang zalim di antara mereka. Dan katakanlah: kami telah beriman kepada (kitab-kitab) yang diturunkan kepada kami dan yang diturunkan kepadamu; Tuhan kami dan Tuhanmu adalah satu; dan kami hanya kepadaNya berserah diri.” (QS. al Ankabut : 46). Sangat jelas dalam Surat Al Ankabut tergambar bahwa setiap orang, lepas dari persoalan apa agamanya, tetap harus dihargai sebagai manusia sesama makhluk Allah Tuhan Yang 
Maha Esa. Sebab Allah SWT sendiri pun menghormati manusia, anak cucu Adam di mana saja ia berada, dengan segala potensi dan perbedaannya. Bahkan perbedaan itu dibuatNya menjadi semenarik mungkin sehingga selalu dirasakan indah, baik-baik saja, oleh masing-masing penganut agama, meskipun sesungguhnya salah.

\section{SEJARAH ISLAM KERUKUNAN UMAT BERAGAMA}

Diskusi mengenai kerukunan umat beragama dalam sejarah Islam dimulai sejak zaman klasik. Rasulullah SAW selain dikenal sebagai Rasul, Beliau juga dikenal sebagai kepala negara. Dalam kapasitasnya sebagai kepala negara proses pengambilan keputusan acapkali dilakukan melalui musyawarah dan mufakat. Meskipun sebagai Rasul memiliki otoritas penuh, namun ia selalu mengajarkan prinsip-prinsip yang sangat mendasar tentang musyawarah demi mempertahankan kehidupan sosial dan politik yang stabil. Khususnya untuk masalah-masalah di luar akidah murni dan ibadah, Nabi tidak pernah ragu untuk bertanya kepada para sahabatnya dan mengubah pendapatnya sesuai dengan hasil musyawarah tanpa mempertimbangkan kelompok suku manapun (Taher, 1998: 142).

Misalnya saat Perang Badar, ketika kaum muslim siap bertahan dari serangan Suku Quraisy, Nabi Muhammad SAW bersama para pengikutnya mengambil posisi bertahan di dekat mata air. Kemudian salah seorang sahabat nabi bernama Hubab bin Munzir, bertanya kepada nabi apakah keputusan untuk mengambil posisi bertahan itu berdasarkan pada wahyu Allah. Jika demikian, dia tidak akan mempertanyakan dan menerima sepenuhnya. Kemudian Rasulullah SAW berkata bahwa itu adalah keputusan strategi perang pribadinya, bukan berdasarkan wahyu Allah SWT. Mendengar jawaban itu, Hubab berkata, bahwa posisi yang diambil Rasulullah SAW bukan posisi yang menguntungkan. Dia menganjurkan kepada nabi dan para sahabat agar mengambil posisi lebih rapat ke mata air, lokasi terdekat ke satu tempat yang menjadi konsentrasi pasukan perang suku Quraisy. Hubab menganjurkan 
kepada nabi agar kaum muslimin pertama-tama mengambil persediaan air di tangki dan menutup mata air dengan lumpur dan batu. Menurut Hubab, saat perang berlangsung pasukan yang dipimpin Rasulullah SAW punya persediaan air yang cukup, sementara pasukan Quraisy justru akan mengalami kekurangan bahkan kelangkaan air. Nabi menerima dengan gembira nasehat Hubab dan ia segera bergerak ke posisi yang baru. Dia juga menginstruksikan semua sahabat agar melaksanakan himbauan Hubab tanpa merasa tidak enak atau merasa kalah (Taher, 1998: 142-143). Jadi dengan demikian, musyawarah adalah segala usaha bersama untuk menemukan titik kesepakatan diantara berbagai pendapat dan kepentingan yang berbeda. Syarat utama untuk mencapai kata mufakat adalah satu sama lain harus rela melepaskan ego personal dan tidak menganggap dirinya yang paling benar. Budaya toleransi perlu dikembangkan guna menghargai hak-hak orang lain dalam mengambil pendapat yang berbeda-beda dan bertentangan.

Penting juga diketahui bahwa bersikap toleran bukan berarti bersikap masa bodoh dan tidak perlu mendakwahkan ajaran kebenaran yang diyakini. Setiap orang yang beriman senantiasa terpanggil untuk menyampaikan kebenaran yang diketahui dan diyakininya, tetapi harus berpegang pada etika dan tata krama sosial serta tetap menghargai hak-hak individu untuk menentukan pilihan hidupnya masing-masing secara sukarela. Sebab, pada hakikatnya hanya ditangan Tuhan lah pengadilan atau penilaian sejati akan dilaksanakan (Taher, 1998: 143). Faktanya, seseorang akan sulit bersikap toleran terhadap agama lain jika terhadap sesama agama saja sulit untuk menghargai perbedaan paham yang muncul. Konflik internal sesama umat seagama ini mudah dijumpai dalam berbagai pemeluk agama besar dunia, dan seperti halnya juga dijumpai pada hubungan antara pemeluk agama yang berbeda, biasanya konflik tersebut semakin tidak jelas manakala kepentingan agama sudah berbaur dengan kepentingan etnis, politis dan ekonomis.

Melihat kenyataan sejarah yang demikian, tantangan yang selalu dihadapi oleh agama-agama sejak dahulu hingga mendatang antara lain adalah 
bagaimana merumuskan langkah konstruktif yang bersifat operasional untuk mendamaikan berbagai kepercayaan yang ada dan cenderung mendatangkan pertikaian antar manusia dengan mengatasnamakan kebenaran Tuhan. Usaha ini tidak hanya diarahkan pada hubungan antar pemeluk agama-agama secara eksternal melainkan lebih dahulu diarahkan pada hubungan intra-umat beragama.

Perang Salib merupakan contoh penegasan agama secara esoterik yang paling mencolok dan sekaligus telah membawa ekses bagi tercorengnya kemuliaan citra agama dan citra kemanusiaan. Konflik antar penganut agama dalam kasus Perang Salib ini menumpahkan darah baik pada pihak umat Kristen maupun umat Islam. Kontak antar pemeluk agama yang berdiri konfliktual ini oleh para orientalis dipopulerkan dengan istilah jihad atau Holy War , suatu istilah yang paradoksal dan tidak enak didengar bagi telinga umat Islam. Konflik berdarah ini sesungguhnya juga terjadi dalam satu agama yang sama entah itu pada Kristen ataupun Islam (Taher, 1998: 146).

Islam sejak semula menganjurkan dialog dengan umat lain, teristimewa umat Kristen. Terhadap pengikut Isa AS dan Musa AS al-Qur'an menggunakan kata Ahl al-Kitab (yang memiliki kitab suci). Penggunaan kata "Ahl" berarti keluarga menunjukkan keakraban dan kedekatan hubungan. Lebih dari itu, pengikut Nabi Muhammad SAW yang terpaksa meninggalkan Mekah untuk menghindari penganiayaan bangsanya sendiri (Arab Jahiliyah) berhijrah ke negara lain, Ethiopia. Di sana mereka diterima dengan baik dan mendapatkan perlindungan oleh Raja Negus (Najashi) yang beragama Kristen. Peristiwa ini menurut Alwi Shihab (1999: 67) menandakan keakraban dan hubungan harmonis antar kedua umat, Islam dan Kristen.

\section{RIWAYAT HIDUP TARMIZI TAHER}

Tarmizi Taher merupakan tokoh kelahiran 7 Oktober 1936 di Padang. Ayah Tarmizi Taher bernama Taher Marah Sutan, sementara ibunya bernama Djawanis. Taher Marah Sutan merupakan seorang nasionalis yang banyak terlibat dalam kegiatan organisasi sosial dan organisasi dakwah seperti Muhammadiyah. 
Dalam memajukan perekonomian, Taher Marah Sutan bersama teman-temannya memiliki perusahaan serikat usaha yang bergerak di bidang perdagangan dan pelayaran (Taher: 2002, 47). Jiwa wirausahanya tidak muncul secara alami, melainkan didukung oleh pengalaman kerjanya di perusahaan Belanda yang bergerak di bidang angkutan perkapalan dan perdagangan. Taher Marah Sutan adalah merupakan tokoh yang memperjuangkan semangat nasionalisme, sehingga ia berharap kepada anaknya kemudian kelak bisa berhasil, yang menggabungkan unsur nasionalisme-religiusitas (Azra: 1998, 444).Sementara ibu dari Tarmizi Taher, yang bernama Djawanis adalah seorang religius yang selalu memperjuangkan amar ma'ruf nahi munkar melalui dan aktivitasnya di organisasi Aisyiyah, sebuah perkumpulan khusus bagi kaum wanita di bawah Muhammadiyah (Azra: 1998, 449).

Sejak kelas 1 SD, usia 7 tahun, Tarmizi Taher satu kelas dengan kakaknya (Tabrani) yang beda usia 1 tahun. Pendidikan SD, ditempuh Tarmizi Taher pada 1943 sampai 1949 di tiga tempat. Pada 1945, Tarmizi Taher sekolah di Padang, tempat sekolahnya Muhammad Yamin. Ketika perang meletus di Padang, 19461947, Tarmizi Taher pindah ke Padang Panjang (Azra: 1998, 449).Pada saat Sekolah Menengah Pertama (SMP) ditempuh oleh Tarmizi Taher pada tahun 1949-1952, yang dijalani selama 3 tahun. Pada awalnya Tarmizi Taher sekolah di Padang Panjang, Kemudian pindah ke Jakarta dan diterima di SMPN 4, yang keberadaan sekolah ini berada di samping departemen yang ia pimpin, Departemen Agama. Setelah lulus dari Sekolah Menengah Pertama, Tarmizi Taher kemudian melanjutkan studinya pada SMA Negeri 1, Jakarta Pusat pada tahun 1952.Tarmizi Taher yang sempat tinggal di rumah pamannya, Ahmad Syafii yang bekerja sebagai pengusaha percetakan kemudian pamannya ini pindah ke Surabaya untuk memimpin percetakan di kota pahlawan tersebut. Tarmizi Taher yang juga ikut kepindahan pamannya itu di Kota Surabaya ia masuk SMA II pada kelas 3, di SMA ini dia bertemu dan bahkan berteman dengan Tri Sutrisno, mantan Wakil Presiden Republik Indonesia. Setamat SMA Tarmizi Taher dan Tri Sutrisno terpisah, karena Tarmizi Taher melanjutkan ke Fakultas Kedokteran 
Universitas Airlangga Surabaya, sedangkan Tri Sutrisno masuk Atekad (Akademi Tekhnik Angkatan Darat) di Bandung.

Saat menjadi mahasiswa Fakultas Kedokteran Universitas Airlangga Surabaya tahun 1956-1964, Iya pernah menjabat ketua dewan perwakilan Mahasiswa, tahun 1962-1963, Ketua senat mahasiswa dan ketua satu dewan mahasiswa Unair, tahun 1963-1964. Bersamaan dengan itu karena sudah masuk TNI Angkatan Laut, dia menjabat ketua pelajar calon Perwira Angkatan Laut, tahun 1963. Sebagai aktivis kampus, dirinya dikenal sebagai tokoh mahasiswa yang sangat antipati dengan komunis/PKI, karena itu ia termasuk golongan orang yang gigih dan dalam Operasi penumpasan Gerakan 30 September PKI. Saat pertemuan dewan-dewan Mahasiswa se-indonesia di Malindo, Sulawesi Selatan tahun 1964, iya termasuk gigih membela rekanrekannya yang berasal dari HMI (Himpunan Mahasiswa Islam) dalam berhadapan dengan CGMI (Central Gerakan Mahasiswa Indonesia) yang pro dengan PKI. Pada tahun 1966-1968 pernah menjadi ketua II dalam himpunan IDI (Ikatan Dokter Indonesia) Surabaya, dan ketua I pengurus besar PPTI (Perkumpulan Pemberantasan Tuberculosa Indonesia) tahun 1973-1979. Sebagai dokter Tarmizi Taher beri kesempatan menambah ilmunya, antara lain mengikuti Medical Observership, US Naval Hospital San Diego, tahun 1972 1973, dan Study for Senior Medical Officer US Navy, Washington tahun 1975. Karir militer Tarmizi Taher pernah mengikuti latihan kilat militer PPKD Surabaya tahun 1960, Latihan militer pertama Sispa XIII Kobangdikal AL Surabaya tahun 1965/1966, serta sekolah staf dan komando (Sesko) ABRI Bagian Laut II tahun 1976/1977, menjabat kepala pusbintal ABRI. (M. Nasir: 1996, 194).

Pada masa orde baru, sebagai Menteri Agama, Tarmizi Taher mendirikan LPKUB (Lembaga Pengkajian Kerukunan Umat Beragama), lembaga tempat dimana para cendekiawan dan pakar berbagai agama, tahun 1993. Tarmizi Taher juga berupaya meningkatkan citra Departemen Agama, mengangkat mutu sekolah yang dikelola Departemen Agama serta menata 
IAIN (Institut Agama Islam Negeri), melahirkan STAIN (Sekolah Tinggi Agama Islam Negeri) yang mulai berkiprah pada tahun akademik 1997/1998. Dalam bidang haji, selain membenahi manajemen dan menambah 2 bandara haji (Solo dan Balikpapan), Tarmizi Taher juga berhasil menghimpun dana abadi sekitar 300 miliar yang berasal dari pengelolaan dana ONH (Ongkos Naik Haji). Pada masanya juga, Berhasil diwujudkan proyek raksasa senilai hampir 50 miliar, yaitu Bayt Alquran dan Museum Istiqlal di Kompleks Taman Mini Indonesia Indah (TMII) pada awal tahun 1997 (Azra: 1998, 417). Pasca menjadi Menteri Agama tahun 1998, Tarmizi Taher kembali ke fakultas kedokteran Unair Surabaya dan menjadi Rektor Universitas Bangkalan (sekarang menjadi Universitas Negeri Trunojoyo). (Taher: 2002, 113). Berbagai penghargaan juga telah banyak diterimanya, antara lain: Satyalencana Dwidya Sista Penegak, 1981; Satyalencana Kesetiaan Dwidya Sistha Dwikora, 1989; Bintang Funun wal Qanun (Seni dan Hukum) di bidang dakwah dari Presiden Mesir Husni Mubarok, 1993 ; Bintang Mahaputra Adipradana, 1996; Jalasena Nararya 1997; Doctor Honoris Causa Temple University Amerika Serikat, 1998; Doctor Honoris Causa dalam bidang dakwah dari UIN Syarif Hidayatullah Jakarta, 2003.

Tarmizi Taher, selain dikenal sebagai Menteri Agama era Soeharto, beliau juga sebagai seorang mubaligh, perhatiannya tentang masalah keummatan adalah perhatiannya secara serius. Hal ini dapat ditelusuri dari karya-karya ilmiahnya yang telah melengkapi masalah ini pada rak-rak perpustakaan Indonesia. Adapun karya-karya Tarmizi Taher yang mempunyai keterkaitan secara langsung tentang kerukunan umat beragama adalah sebagai berikut; Menyegarkan Aqidah Tauhid Insan: Mati di Era Klenik (2002). Buku ini diberi pengantar oleh Azyumardi Azra, yang mengatakan bahwa isi buku adalah semangat puritanisme Tarmizi Taher yang ingin berbagi pengalaman dan pengetahuan kepada pembaca. Menurutnya, Konstruksi aqidah tauhid yang bersih dan kokoh dapat membawa umat siap berkompetisi dalam ilmu, karir dan kepemimpinan bangsa yang dirahmati Allah SWT. Apa yang dimaksudkan oleh Tarmizi Taher merupakan keharusan yang dimiliki seorang pendidik dan 
juru dakwah; Buku yang berjudul Demokrasi Terbuka (1998). Buku ini sebagai buku pertama yang mencoba memberikan pengertian kepada masyarakat bahwa Pancasila adalah ideologi terbuka. Pancasila telah dirumuskan sebagai pencerminan dari nilai-nilai tradisional dan adat-istiadat yang telah hidup dalam masyarakat Indonesia, dan dipertahankan oleh masyarakat Indonesia selama berabad-abad. Pancasila juga telah disepakati oleh para pendiri Republik Indonesia sebagai pedoman utama untuk kehidupan dalam masyarakat yang pluralistik dan heterogen di Indonesia yang merdeka; Pandangan Tarmizi Taher mengenai kerukunan umat beragama tampak pada karyanya yang berjudul Menuju Ummatan Wasthan Kerukunan Beragama di Indonesia (1998). Buku ini menjelaskan kerukunan hidup beragama adalah hal penting dalam konteks negara-bangsa Indonesia, yang tidak hanya majemuk dari suku bangsa, budaya dan sistem sosialnya, tetapi juga majemuk dari segi kepercayaannya. Pluralisme agama di Indonesia secara jelas terwujud dalam kehadiran berbagai agama besar di Indonesia (Katolik, Protestan, Islam, Hindu, Budha, bahkan aliran-aliran yang diakui oleh pemerintah). Meskipun kaum muslimin merupakan mayoritas penduduk di Indonesia, namun tidak bisa dikatakan bahwa Islam menjadi satu-satunya agama resmi negara.

\section{ANALISIS PEMIKIRAN TARMIZI TAHER}

\section{SEJARAH KERUKUNAN UMAT BERAGAMA MENURUT TARMIZI}

\section{TAHER}

Penerapan semangat kerukunan hidup umat beragama di Indonesia tidak terlepas dari warisan Islam klasik. Sejak masa Rasulullah SAW, umat Islam sudah memiliki pengalaman membangun harmonisasi kehidupan antar penganut agama. Nabi sendiri memulai pengalaman itu ketika hijrah ke Madinah pada tahun 622 M. Pembentukan negara kota Madinah, tidak diragukan lagi merupakan momen historis sejauh menyangkut implementasi kerangka teologi, doktrin dan gagasan kerukunan keagamaan Islam terhadap para penganut agama-agama lain, dalam konteks ini khususnya agama Yahudi dan Nasrani (Azra, 1999: 36). 
Tarmizi Taher (2002: 58) menjelaskan bahwa momen sejarah itu adalah penetapan piagam Madinah atau sering disebut Konstitusi Madinah oleh Muhammad SAW. Dalam konstitusi ini secara tegas dinyatakan hak-hak Penganut Agama Yahudi untuk hidup berdampingan secara damai dengan kaum muslim. Kaum Yahudi menerima Konstitusi Madinah secara sukarela. Berkat konstitusi ini, kaum Yahudi terangkat dari sekedar klien kesukuan menjadi warga negara yang sah. Dalam seluruh entitas politik atau negara Islam sepanjang sejarah, kaum Yahudi tidak pernah kehilangan status ini.

Konstitusi Piagam Madinah oleh Rasulullah SAW tidak dijadikan instrumen untuk mewujudkan persatuan ummah (umat). Kata "umat" digunakan untuk menyebutkan populasi orang-orang yang telah masuk Islam, tanpa melihat suku, asal-usul, ras, kedudukan sosial dan sebagainya. Penggunaan kata "umat" di sini menjadi penghimpunan bagi seluruh orang yang beriman menurut ajaran Islam. Dengan demikian, konsep persatuan dimaksud adalah kesatuan atas dasar ikatan agama. Tetapi cakupan persatuan tersebut menjadi lebih luas setelah memasukkan golongan Yahudi menjadi satu umat yang paralel (berdampingan) dengan kaum muslim. Hal ini menunjukkan bahwa Muhammad SAW tidak bermaksud mendirikan Negara yang eksklusif bagi kaum muslimin.

Tarmizi Taher mencoba menjelaskan sejarah transmisi pengetahuan dalam hubungan kerukunan umat beragama dengan pengalaman Islam Indonesia. Menurutnya, Pengalaman Islam di Indonesia relatif berbeda dengan pengalaman Islam di kawasan-kawasan lain. Jika di Timur-Tengah, Asia Selatan atau anak benua India mengalami penaklukan politik langsung oleh kekuatan-kekuatan militer muslim dari Arabia, Indonesia tidak pernah mengalami proses seperti itu. Oleh sebab itu, sering dikatakan oleh para ahli bahwa Indonesia merupakan kawasan muslim yang paling kurang mengalami Arabisasi (Taher: 2002, 38). Penyebaran Islam di Indonesia pada umumnya berlangsung melalui proses yang sering disebut sebagai penetration pasifique (penyebaran secara damai), pertama kali melalui perkenalan Islam oleh para 
pedagang yang datang dari Timur-Tengah sejak abad ke-8 dan abad ke-9, yang selanjutnya melalui konversi massal berkat usaha para guru sufi yang mengembara dari satu tempat ke tempat lain. Proses semacam ini, pada gilirannya memberikan warna yang cukup khas bagi Islam Indonesia, yakni Islam yang akomodatif dan inklusif, kalau tidak dikatakan cenderung sinkretisme dengan kepercayaan lokal (Taher: 2002, 7).

Menurut Tarmizi Taher, puncak dari teologi kerukunan Islam di Indonesia adalah penerimaan Pancasila sebagai dasar negara dan ideologi nasional pada tanggal 18 Agustus 1945. Pada konteks hubungan antar agama di Indonesia, pancasila dapat dikatakan merupakan perwujudan dari panggilan untuk mengembangkan kalimatan sawa'. Dari proses penerimaan Pancasila itu, jelas terlihat bahwa para pemimpin Islam lebih mementingkan kerukunan dan integritas nasional daripada mendahulukan kepentingan Islam dan umat muslim belaka (Taher: 2004, 78). Pengembangan kerukunan hidup antar umat beragama di Indonesia sulit dilakukan pada tingkatan konsep-konsep teologi sentral, yang merupakan inti dari eksklusifisme masing-masing agama. Sulit dibayangkan jika para pemeluk agama dalam hal ini Islam dan Kristen menerima usul dari Montgomery Watt Agar pihak Kristen mempertimbangkan kembali doktrin bahwa "Yesus merupakan satu-satunya anak Tuhan" atau agar kaum muslimin menafsirkan kembali doktrin tentang finalitas Islam dan Muhammad sebagai rasul terakhir (Taher: 2004, 83).

Jadi, kerukunan hidup antar umat beragama seperti menurut Tarmizi Taher dapat dikembangkan lebih pada tingkatan-tingkatan non teologi Sentral. Tegasnya mencakup tingkatan etis, sosial, politis dan ekonomis. Namun pengembangannya pada tingkatan ini memerlukan beberapa prasyarat penting, antara lain : Penghapusan saling kecurigaan dan ketakutan, sebaliknya lebih mengembangkan kejujuran, keadilan dalam mengembangkan misi dan dakwah agama masing-masing. Pada pihak lain, diperlukan sikap respek dan toleransi terhadap perbedaan-perbedaan yang ada di antara berbagai agama (Taher: 2002, 66). Hanya dengan begitu dapat diharapkan bagi terciptanya kehidupan 
keagamaan yang harmonis dan rukun, serta merupakan sumbangan yang amat berharga bagi integrasi nasional dan kemajuan Indonesia.

\section{KERUKUNAN BERAGAMA DI INDONESIA}

Kondisi keberagamaan di Indonesia sejak pasca krisis tahun 1997 sangat memprihatinkan. Konflik bernuansa agama terjadi di beberapa daerah seperti di Poso dan Ambon. Konflik tersebut sangat mungkin terjadi karena kondisi rakyat Indonesia yang multietnis, multi agama dan multi budaya. Belum lagi dengan masyarakat Indonesia yang mudah terprovokasi oleh pihak yang merusak watak bangsa Indonesia yang suka damai dan rukun. Sementara itu krisis ekonomi dan politik terus melanda bangsa Indonesia, sehingga sebagian bangsa Indonesia sudah sangat tertekan baik dari segi ekonomi, politik maupun agama. Terakhir peristiwa dihancurkannya gedung World Trade Center pada tanggal 11 September 2001 dan Bom Bali pada tanggal 12 Oktober 2002 yang menewaskan 180 orang, yang berdampak diidentikkan nya umat Islam dengan teroris dan dituduhnya Indonesia sebagai sarang teroris.

Sasaran pembangunan dalam bidang agama sebenarnya adalah terciptanya suasana kehidupan beragama dan kepercayaan terhadap Tuhan Yang Maha Esa yang penuh keimanan dan ketakwaan, kerukunan yang harmonis antar umat beragama dan secara bersama-sama memperkuat landasan spiritual, moral dan etika bagi pembangunan nasional. Sebagai warga negara Indonesia, bersama pemeluk agama lain, Islam tidak membenarkan umat Islam bersikap eksklusif dalam tugas dan kewajiban bersama sebagai anggota warga negara Indonesia. Aqib Suminto (1987: 17) dalam bukunya yang berjudul Politik Islam Hindia Belanda menyebutkan bahwa penyebaran Islam di nusantara ini dilakukan dengan cara damai, sementara umat Kristen bahkan melakukan dengan cara-cara yang tidak wajar. Meskipun demikian, tidak bisa dinafikan bahwa terjadi pula di belahan tempat persaingan yang tidak sehat bagi agama-agama ketika masing-masing bertemu, khususnya Islam dan Kristen. Sehingga dengan demikian, hubungan masing-masing agama 
kadangkala mengalami kerukunan namun bisa berbalik menciptakan suasana yang tidak aman. Perlu juga diketahui persaingan agama-agama tersebut bukan merupakan khas yang terjadi di Indonesia saja, bahkan merupakan kontinuitas hingga kini yang telah lama terjadi dimana tempat agama itu lahir, yakni di Timur Tengah. Dalam setiap konfrontasi yang terjadi selama ini meluas sampai ke Asia dan Afrika yang dipicu dalam rangka mencari pengikutnya masingmasing.

Dalam kaitan pergaulan agama dan umat ini, kaum Muslim dan Kristen di berbagai daerah di tanah air telah rukun sejak masa lalu. Hal ini dapat dilihat di bagian wilayah barat Indonesia dan timur Indonesia yang hidup dalam satu keluarga. Suasana kerukunan umat beragama seperti itu, memelihara aqidah bagi umat Islam menjadi sesuatu yang sangat fundamental, karena dari aqidah itulah yang membedakan Islam dan non Islam yang sama-sama merupakan anak cucu Nabi Ibrahim AS. Keesaan Allah bagi Islam adalah uncompromising alias tanpa kompromi atau juga harga mati, sesuatu yang tidak bisa tawarmenawar, tetapi sebagai umat beragama yang berbeda tidak perlu mencoba untuk mempersamakan aqidah. Dalam kaitan perbedaan itu, sebaiknya kita kembali kepada moto berbangsa: Bhinneka Tunggal Ika, Berbeda dalam iman tetapi tetap satu sebagai suatu bangsa (Taher, 2002: 58). Dalam sejarah Islam nampaknya tidak ada masalah mengenai kerukunan antar umat Islam dan Kristen, karena Nabi Muhammad SAW telah mencontohkan kerukunan umat Islam antara kaum musyrikin dan Yahudi di Madinah. Para sarjana modern kagum dengan Civil Society yang dibangun dan dibina oleh Nabi Muhammad SAW pada kurun waktu 15 abad yang silam. Bahkan sesungguhnya Nabi Muhammad SAW membuat perjanjian tersendiri yang menjamin kebebasan dan keagamaan kaum Kristen di mana saja sepanjang masa (Nurcholis Madjid, 2000:195). Menurut Dawam Rahardjo (1989: 123), di Madinah Rasulullah SAW dan para sahabatnya melakukan konsistensi (penyadaran) melalui penanaman kecintaan pada iman. Atas dasar iman itulah, dibangun persaudaraan dengan menghilangkan perselisihan. Jika terjadi perselisihan maka Nabi Muhammad SAW mengupayakan jalan rekonsiliasi. Bangunan 
masyarakat yang saling menghargai dan menghormati itulah selanjutnya juga dilakukan dan dicontoh oleh para khalifah pengganti Nabi Muhammad SAW.

\section{URGENSI KERUKUNAN UMAT BERAGAMA DI INDONESIA}

Banyak pertanyaan berkaitan dengan keagamaan di Indonesia, diantara pertanyaan penting itu salah satunya adalah bagaimana respon penganut agama di Indonesia terhadap keanekaragaman. Menurut Tarmizi Taher (2004: 91) Keanekaragaman akan menjadi kekuatan bangsa manakala agama-agama mampu hidup berdampingan secara menyenangkan dalam sebuah negara. Dalam perspektif keanekaragaman, Situasi ini dapat diwujudkan jika masingmasing agama mengakui prinsip umum sebagai landasan bersama dalam merespon situasi keanekaragaman.

Keanekaragaman mengandung bahaya manakala pengenalan kriteria sendiri pada agama lain dihubungkan dengan kegiatan misioner sehingga pada situasi yang bersamaan menimbulkan kemungkinan untuk menobatkan penganut agama lain. Hal ini seringkali mendapatkan legitimasinya dalam ajaran-ajaran tradisi keagamaan, baik dalam Islam, Kristen maupun agama lain. Ironisnya lagi, cara menyebarkan ajaran kepada orang lain dibuat militan dan eksklusif. Tidak mengherankan dari situasi ini melahirkan gerakan fundamentalisme agama (Nurcholis: 2001, 81). Namun bahaya itu menurut Tarmizi Taher (1987: 51) Akan dapat segera diatasi dengan saling membagi pemahaman particular tentang agama dengan orang lain. Jangan saling membagi pemahaman ini, diharapkan dapat menyebabkan perkembangan rohani dan memperkaya semua pihak. Oleh sebab itu, para penganut agama harus belajar dan menghormati bahasa dan bentuk-bentuk gagasan penganut agama lain selama tidak disertai mesianis. Dengan demikian, kerukunan dan toleransi beragama jelas merupakan hal pokok untuk menjamin persatuan bangsa yang plural.

Melihat fenomena itu, Pemerintah Indonesia mengembangkan kerukunan dan toleransi beragama melalui konsep Trilogi kerukunan (Taher, 
1997: 3), yaitu: Pertama, kerukunan intern umat beragama, bahwa setiap agama mengakui adanya aliran-aliran, mazhab-mazhab atau kelompokkelompok yang tumbuh dari perbedaan-perbedaan dalam memahami dan menafsirkan doktrin-doktrin agamanya. Perbedaan intern sebaiknya tidak menjadi sumber perpecahan dan konflik. Semua aliran dan mazhab mengembangkan sikap saling menghargai, memahami dan toleransi. Kedua, kerukunan antar umat beragama. Maksudnya antar penganut agama saling menghormati dan menghargai. Semua umat beragama harus meyakini bahwa ada aspek-aspek teologis dan doktriner dalam agama yang meliputi keimanan, keyakinan dan komitmen sebagai bagian yang sangat fundamental dan personal. Tidak ada seorang pun berhak mengganggu atau mempertanyakan dimensi-dimensi substansif agama orang lain. Karena itu, perbedaan-perbedaan teologis dan doktriner sebaiknya tidak menjadi sumber konflik. Pemelukpemeluk agama sebaiknya membangun saling pengertian dan mencari landasan yang sama dalam pergaulan sosial yang didasarkan pada toleransi dan saling menghargai. Ketiga, kerukunan antar penganut agama dengan pemerintah. Model toleransi ini dipandang cukup penting untuk mewujudkan persatuan dan kesatuan nasional. Pemerintah mempunyai komitmen untuk tidak ikut campur dalam aspek-aspek teologis dan doktriner semua agama. Namun, demi persatuan nasional, pemerintahan dari waktu ke waktu dapat mengambil kebijakan-kebijakan dan aturan-aturan tertentu untuk membangun kehidupan keagamaan yang lebih harmonis dan sehat. Untuk memenuhi tujuan ini diperlukan suasana saling percaya yang dibangun oleh kerjasama antar penganut agama dengan pemerintah.

Menurut Tarmizi Taher (1998: 59) kerukunan antar penganut agama sudah terbangun sejak 1980. Kebijakan pemerintahan cukup memberikan pengaruh signifikan terhadap terciptanya hubungan baik dan dinamis antara Muslim dan Kristen di Indonesia. Bahkan ada indikasi, baik secara kuantitatif maupun kualitatif, bahwa kehidupan keagamaan di Indonesia sedang mengalami proses revitalisasi atau kebangkitan. Orang menjadi makin religius dalam orientasi mereka dan makin menolak ke agama dalam menyelesaikan 
masalah-masalah keagamaan. Indikasinya, rumah ibadah seperti masjid, gereja dan lainnya dipenuhi jamaahnya masing-masing, sehingga jumlah rumah ibadah berkembang cepat. Perkembangan jumlah rumah ibadah ini diikuti perkembangan lembaga-lembaga pendidikan keagamaan. Di Indonesia, pendidikan agama harus diberikan di semua tingkatan pendidikan.

Dalam perspektif sosial religius, berbagai kerusuhan sosial yang terjadi di Indonesia tidak langsung dapat dikaitkan dengan masalah-masalah agama. Para ilmuwan dan peneliti justru mengambil kesimpulan bahwa berbagai kerusuhan yang terjadi di Indonesia lebih disebabkan oleh masalah politik, sosial, ekonomi dan sebagainya (Taher: 1998, 102). Secara sosiologis misalnya, Masyarakat Indonesia sekarang sedang mengalami perubahan sosial yang cepat diakibatkan oleh pembangunan nasional. Perubahan sosial tersebut disertai dengan proses globalisasi yang juga tengah melanda Indonesia. Konsekuensinya, segmen- segmen masyarakat tertentu sedang mengalami disorientasi, dislokasi dan alienasi yang semuanya sangat kondusif bagi keresahan sosial.

Oleh sebab itu menurut Tarmizi Taher (2002: 86) harus merekomendasikan perlunya dikembangkan kebangkitan agama yang kualitatif. Tokoh-tokoh agama di Indonesia sebaiknya secara bersama-sama melakukan upaya-upaya untuk memberikan substansi pada ajaran-ajaran keagamaan yang formal, sehingga pelaksanaan agama menjadi lebih bermakna, tidak hanya pada tingkat individual tetapi juga sampai pada dataran sosial. Dengan demikian, agama dapat menjadi cahaya penerang dalam seluruh aktivitas keseharian. Agama mampu menjadi sumber etika sosial, yang dapat membangkitkan kepedulian etis dan kejujuran pemeluk agama. Hal ini akan memberi pedoman untuk menghindarkan diri pada tindakan yang tidak bermoral dan tidak etis. Pada gilirannya, hal ini akan menurunkan dan akhirnya menghilangkan penyimpangan sosial seperti korupsi pelanggaran hukum dan penyakit sosial lainnya. 
Azyumardi Azra menulis dalam bukunya Menteri-menteri Agama RI (Azra: 1998, 422), dikatakan bahwa untuk mengembangkan dan memperkokoh kerukunan umat beragama di Indonesia, Tarmizi Taher merumuskan rencana strategis jangka pendek dan jangka panjang. Rencana strategis jangka pendek dibagi ke dalam tiga fase. Pertama, Memecahkan masalah-masalah yang dapat mempengaruhi kerukunan beragama. Kedua, Menyelesaikan kecurigaan timbal balik antara umat Islam dan Kristen. Ketiga, memperkuatkan seluruh umat beragama dalam persatuan dan kesatuan bangsa. Untuk menciptakan kondisi seperti itu, Tarmizi Taher berharap banyak kepada ahli-ahli Ilmu Sosial dan kaum intelektual umumnya sangat diperlukan, khususnya dalam memecahkan masalah yang muncul dari hubungan antar agama secara profesional, akademis dan ilmiah, sehingga dapat dipertanggungjawabkan. Dalam kaitan ini, Departemen Agama membentuk lembaga pengkajian kerukunan umat beragama (LPKUB) Dalam Kongres pertama agama-agama di Yogyakarta pada bulan Oktober 1993. Tujuan pertama dari LPKUB adalah mengkaji dan mengembangkan pemikiran keagamaan tentang hubungan yang harmonis di antara pemeluk-pemeluk agama yang berbeda; Kedua, Menyumbangkan pemikiran keagamaan kepada pemerintah tentang hubungan yang harmonis di antara pemeluk pemeluk agama yang berbeda. Dengan peran yang strategis dalam menciptakan hubungan beragama yang harmonis dan rukun, maka tentu kehadiran lembaga disambut oleh kalangan intelektual agama yang berbeda yang mendambakan ketenangan dan kedamaian sehingga setiap agama yang diakui masyarakat dan bangsa eksistensinya di bumi Nusantara terwakili dalam LPKUB. Tidak hanya itu, LPKUB telah membuka cabang-cabang di Ambon dan Medan, 2 wilayah yang dikenal punya khazanah kultural dalam kerukunan hidup beragama.

Sedangkan rencana strategis jangka panjang dirumuskan untuk menunjang akselerasi kebangkitan nasional kedua bangsa Indonesia, dimana umat beragama mempunyai peranan dan posisi sangat penting. Rencana strategis jangka panjang ini juga terdiri dari tiga tahap; Pertama, mempertahankan dan meningkatkan stabilitas kerukunan hidup umat 
beragama; kedua, mendorong partisipasi berkelanjutan umat beragama dalam sains teknologi dan kesejahteraan jasmani dan rohani. Ketiga, meningkatkan peran dan partisipasi umat beragama dalam kebangkitan nasional.

Indonesia merupakan sebuah negara yang plural, baik dalam aspek etnik, budaya, adat istiadat maupun teologis. Keragaman itu selama ini dipandang sebagai suatu kelemahan atau kekurangan, seharusnya justru dipandang sebagai keindahan serta diyakini sebagai rahmat dan kekayaan yang diberikan Tuhan. Menurut Tarmizi Taher (2004: 16), dengan membiasakan diri hidup dalam keragaman, bangsa Indonesia memiliki modal sosial dan pengalaman memasuki kehidupan global yang ditandai dengan perjumpaan berbagai tradisi dan kecenderungan pemikiran yang berbeda-beda. Ditegaskan kembali oleh Tarmizi Taher (2002: 58), modal sosial tersebut mengasumsikan semua kalangan bahwa keragaman atau pluralisme yang menjadi karakteristik bangsa Indonesia bukan merupakan sesuatu yang baru, tetapi muncul sejak awal sejarah Indonesia terbentuk. Semboyan Bhinneka Tunggal Ika, memberikan pelajaran agar semua penduduk Indonesia menghayati diri mereka sebagai suatu bangsa, satu tanah air, satu bahasa dan satu tujuan nasional yaitu terciptanya sebuah masyarakat adil dan makmur berdasarkan Pancasila sebagai satu-satunya asas dan pedoman utama dalam kehidupan berbangsa dan bernegara.

Tarmizi Taher (2004: 27) menyebutkan ada empat macam komitmen yang patut dipegang oleh semua penganut agama untuk menciptakan kerjasama positif antar umat beragama di Indonesia. Pertama, komitmen terhadap budaya non violence (tidak dengan cara kebengisan atau kekerasan) dan penghargaan terhadap kehidupan. Kedua, komitmen terhadap budaya solidaritas dan keadilan ekonomi. Ketiga, komitmen terhadap budaya toleran dan hidup saling mempercayai. Keempat, komitmen terhadap budaya persamaan hak dan persamaan antara laki-laki dan perempuan.

Untuk mewujudkan kerukunan umat beragama, Tarmizi Taher tidak hanya melakukannya pada tingkat nasional (Indonesia), melainkan juga pada 
tingkat yang lebih besar, dunia. Pada tahun 1997, Tarmizi Taher berhasil berbicara di ranah internasional tentang hubungan Islam-Kristen dalam suatu forum yang belum pernah terjadi di Indonesia. Oleh sebab itu, Tarmizi Taher mendapat sanjungan dan pujian saat berlangsungnya konferensi internasional hubungan Islam-Kristen di Hotel Horizon, Jakarta pada tanggal 7 Agustus 1997. Pada acara tersebut turut hadir direktur pusat kajian hubungan antar agama dari Goergetown University Amerika Serikat, John L Esposito dan John C Raines. Kedua Profesor ini memuji dan menyampaikan kekagumannya kepada Tarmizi Taher dalam acara tersebut, sehingga Menteri Agama asal Minang itu diundang untuk tampil berbicara pada Temple University USA (Azra, 1998: 417). Berhasilnya Tarmizi Taher juga ditandai dengan diterimanya beliau bersama tokoh-tokoh agama oleh Sri Paus di Vatikan, 1995. Terselenggaranya berbagai pertemuan tingkat internasional di Indonesia yang berkaitan dengan masalah keagamaan juga melibatkan Tarmizi Taher. Terakhir, pertemuan Menteri-Menteri Agama negara OKI (Organisasi konferensi Islam) pada Oktober 1997, serta diundangnya Tarmizi Taher ke sejumlah universitas di Barat, tak lain berkat reputasinya dalam melakukan dialog dan lobi dengan berbagai kalangan, terutama dalam hal membangun dialog untuk tujuan kerukunan umat beragama.

Ide besar yang dilahirkan oleh Tarmizi Taher dalam menciptakan kerukunan beragama di Indonesia ini, dengan cepat mendapat sambutan dari berbagai kalangan. Mahmoud Ayoub dari Temple University mengemukakan, Indonesia pantas jadi kajian studi keagamaan di Barat, khususnya Universitas di Amerika, mengingat Pancasila yang mengayomi agama dan umat beragama terlihat sebagai satu alternatif dari negara yang hanya menerapkan paham sekuler atau teokratis. Pengamat sosial politik Fachry Ali mengatakan bahwa konferensi tersebut setidaknya telah menghilangkan rumor, citra negatif tak berdasar yang ditudingkan kepada Indonesia, Islamisasi di Timor Timur dan Irian Jaya yang banyak bergema di Barat, kini bisa dibantah sendiri oleh para pakar tersebut. Alwi Shihab dari IAIN Syarif Hidayatullah (sekarang UIN Syarif Hidayatullah) Jakarta, menyatakan pula hampir semua pakar yang hadir 
dalam konferensi itu menilai bahwa Indonesia, dengan peran Departemen Agama yang dipimpin oleh Tarmizi Taher telah berprestasi besar dalam ikut berperan memecahkan salah satu persoalan dunia yaitu menciptakan keharmonisan hubungan antar agama, khususnya Islam dan Kristen (Azra, 1998: 418)

Meskipun kerukunan hidup beragama sangat baik dan kesemarakan beragama terlihat dimana-mana, bukan berarti kehidupan umat beragama bebas dari masalah. Ajaran agama yang tumbuh dalam kehidupan pribadi dan masyarakat, bahkan sebagian sudah menyatu dalam kehidupan sosial budaya, Tetaplah selalu menghadapi berbagai tantangan yang jika tidak diantisipasi dapat menjauhkan umat dari nilai-nilai keagamaan dan bahkan sebaliknya dapat saja agama dianggap sebagai faktor penghambat. Hal itu disebabkan karena agama bisa menjadi perekat persatuan dan kesatuan bangsa namun pada sisi lain dapat juga menjadi penyebab timbulnya disintegrasi bangsa. Dalam hal ini, Tarmizi Taher mengatakan bahwa semua umat beragama beserta para pemuka agamanya diharapkan secara bersama-sama mau mendukung semua program pembangunan. Tantangan dalam pembangunan adalah tantangan bagi umat beragama. Masalah dampak globalisasi misalnya, merupakan tantangan bagi keberhasilan pembangunan, dan ini juga berpengaruh ke dalam kehidupan umat beragama. Begitu juga soal kemajemukan bangsa, termasuk agama, harus dapat dihadapi secara bersama-sama. Mantapnya kehidupan umat beragama termasuk kerukunan umat bukanlah suatu barang jadi tapi akan terus dalam proses yang tak pernah berhenti (Azra: 1998, 426).

Tantangan bagi agama-agama dewasa ini adalah globalisasi. Menurut Tarmizi Taher (2002: 51), era globalisasi ini setiap agama dan negara tidak dapat mengklaim dunia ini milik satu agama. Akan tetapi milik semua manusia yang ada di dunia ini. Tujuannya adalah agar agama-agama satu sama lain dapat survive maka harus saling menghormati eksistensinya. Tarmizi Taher (1996: 171) menjelaskan lebih lanjut bahwa dalam hidup di era keterbukaan masyarakat harus sanggup hidup dalam perbedaan dan menghadapi perbedaan. 
Tidak perlu menyembunyikan perbedaan agama dalam era keterbukaan sekarang ini dan menutupi perbedaan itu. Hal ini dijamin oleh negara dalam kebebasan beragama sebagai suatu bangsa yang majemuk agama dan suku.

\section{KESIMPULAN}

Indonesia merupakan negara dengan tingkat pluralisme yang sangat tinggi sekaligus menjadi karakteristik bangsa ini. Oleh sebab itu, seharusnya keberagaman menjadi modal besar bagi bangsa Indonesia. Meskipun demikian, keberagaman bisa menjadi pemicu konflik masyarakat di Indonesia. Keberagaman masyarakat Indonesia yang menjadi isu sensitif adalah keberagaman agama. Banyak konflik sosial yang terjadi dan melibatkan isu agama sehingga menjadi konflik agama. Menurut Tarmizi Taher, Pancasila dapat dikatakan merupakan perwujudan dari panggilan untuk mengembangkan kalimatan sawa' (titik temu agama-agama). Proses penerimaan Pancasila itu, terlihat bahwa para pemimpin Islam lebih mementingkan kerukunan dan integritas nasional daripada mendahulukan kepentingan Islam dan umat muslim. Selain itu, untuk menciptakan kehidupan yang damai, maka terdapat 4 komitmen yang harus dilakukan, yakni komitmen terhadap budaya non violence dan penghargaan terhadap kehidupan, komitmen terhadap budaya solidaritas dan keadilan ekonomi, komitmen terhadap budaya toleran dan hidup saling mempercayai, dan komitmen terhadap budaya persamaan hak dan kemitraan antara laki-laki dan perempuan.

\section{Daftar Pustaka}

Azra, Azyumardi. 1999. Konteks Berteologi di Indonesia: Pengalaman Islam. Jakarta: Paramadina. , 1998. Menteri-menteri Agama RI: Biografi Sosial Politik. Jakarta: PPIM.

Gogali, L. 2009. Konflik Poso Suara Perempuan dan Anak Menuju Rekonsiliasi Ingatan. Yogyakarta: Galangpress.

Madjid, Nurcholis. 2000. Islam Doktrin dan Peradaban: Sebuah Telaah Kritis tentang Masalah Keimanan, Kemanusiaan, dan Kemodernan. Jakarta: Paramadina. 
,2001. Pluralisme Agama: Kerukunan dalam Keragaman. Jakarta: Kompas.

Pulungan, J Sayuthi. 1994. Prinsip-prinsip Pemerintah dalam Piagam Madinah: Ditinjau dari Pandangan al-Qur'an. Jakarta: Raja Grafindo Persada.

Rahardjo, M Dawam. 1989. Perspektif deklarasi Mekah: Menuju Ekonomi Islam. Bandung: Mizan.

Shihab, Alwi. 1999. Islam Inklusif: Menuju Sikap Terbuka dalam Beragama. Bandung: Mizan.

Sjadzali, Munawir. 1993. Islam dan Tata Negara: Ajaran, Sejarah dan Pemikiran. Jakarta: UI-Press.

Suminto, Aqib. 1987. Politik Islam Hindia Belanda. Jakarta: LP3ES.

Taher, Tarmizi. 1998. Menuju Umatan Wasathan: Kerukunan Beragama di Indonesia. Jakarta: Pusat Pengkajian Islam dan Masyarakat. ,1996. "Islam dan Isu Globalisasi: Perspektif Budaya dan Agama" dalam Agama dan Dialog Antar Peradaban. Jakarta: Paramadina. ,1997. HAM dan Pluralisme Agama. Jakarta: PKSK. , 2002. Menyegarkan Akidah Tauhid Insani: Mati di Era Klenik. Jakarta: Gema Insani Press.

, 2004. Menjadi Muslim Moderat: Beragama di Tengah Peradaban Global. Jakarta: Hikmah.

Tamara, M. Nasir dan Elza Peldi Taher (ed). 1996. Agama dan Dialog Antar Peradaban. Jakarta: Paramadina.

Tim Penyusun. Undang-Undang Dasar Republik Indonesia 1945 dan Perubahannya. Jakarta: Penabur Ilmu. 